\title{
PROFILE BENIGN TYPE OF CHRONIC SUPPURATIVE OTITIS MEDIA IN GENERAL HOSPITAL OF THE CHRISTIAN UNIVERSITY OF INDONESIA
}

\author{
Fransiskus Harf Poluan ${ }^{1}$, Bambang Suprayogi Resi Utomo ${ }^{1}$ and Jaene Dharmayanti ${ }^{1}$ \\ ${ }^{1}$ Medical Faculty, Universitas Kristen, Jakarta, Indonesia
}

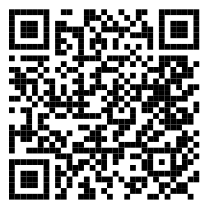

Received 6 April 2021

Accepted 21 April 2021

Published 30 April 2021

Corresponding Author

Fransiskus Harf Poluan, fransiskus

.poluan@uki.ac.id

DOI 10.29121/

granthaalayah.v9.i4.2021.3863

Funding: This research received no specific grant from any funding agency in the public, commercial, or not-for-profit sectors.

Copyright: (C) 2021 The Author(s). This is an open access article distributed under the terms of the Creative Commons Attribution License, which permits unrestricted use, distribution, and reproduction in any medium, provided the original author and source are credited.

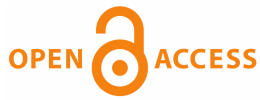

\section{ABSTRACT}

Chronic Suppurative Otitis Media (CSOM) Tubotympanic Type is a CSOM without cholesteatoma, limited to the mucosa, and seldom causes complications. According to WHO, the incidence of the CSOM is estimated to be $65-330$ million worldwide. Prevalence CSOM in Indonesia is 3,9\%. According to a survey conducted in 7 provinces in 1996 in Indonesia, most middle ears morbidity is CSOM, especially the CSOM benign type 3\%. This study's objective was to identify Profile Benign Type of CSOM at the General Hospital of the Christian University of Indonesia. This study uses a descriptive method and retrospective cross-sectionals. Data retrieval using the secondary database on the patient's medical records. The sample obtained is 60 patients with a total sampling from January 2017 - December 2018. Based on the research result, the highest proportion based on gender is female 33 people (55\%). Based on age, mainly in $55-59$ years ten people $(16,7 \%)$. Based on the infected ear is right ear 35 people $(58,3 \%)$ and based on clinical symptoms, is otorrhea by 46 people $(76,7 \%)$. Based on risk factor was that there were 53 people $(88,3 \%)$ and history of otitis media. Based on the tympanic membrane's perforation, which is a central perforation of 57 people (95\%).

Keywords: Csom Benign Type, Prevalence

\section{INTRODUCTION}

Chronic suppurative otitis media (CSOM) is a chronic inflammation of the middle ear due to tympanic membrane perforation and continuous discharge, and hearing loss Singer et al. (2018). Generally, chronic suppurative otitis media is divided into benign type CSOM and malignant type CSOM. Benign CSOM is a type of CSOM that only affects the mucosa, does not have cholesterol, and rarely causes complications. Meanwhile, the malignant type of CSOM is dangerous because of cholesterol, marginal perforation and sometimes subtotal. The malignant type of CSOM usually 
causes complications that occur in CSOM

Chronic suppurative otitis media is considered a complication of acute otitis media, and the risk factors affecting CSOM are unclear. Upper respiratory tract infections and poor socioeconomic conditions (slum environment, poor hygiene, and nutrition) may be associated with chronic suppurative otitis media development Rout et al. (2014).An infection is usually caused mainly by a bacterial infection. The types of bacteria that cause CSOM are different from the types of bacteria in OMA. In CSOM, bacteria can be aerobic (pseudomonas aeruginosa, Escherichia coli, S.aureus, Streptococcus pyogenes) and anaerobes (Propionibacterium, Bacteroides). In AOM, the bacteria found can be Streptococcus pneumonia, Staphylococcus aureus, Haemophilus influenza, and Micrococcus catarrhalis Chonmaitree et al. (2017).

Complicated or uncomplicated CSOM is a disease of the middle ear that generally occurs in developing countries. In developed countries like the UK, it is around $0.9 \%$. According to WHO, the incidence of CSOM is estimated to reach $65-330$ million worldwide and around 60\% experience hearing loss "Chronic suppurative otitis media: burden of illness and management options" (2004).CSOM is a disease that also affects hearing. From WHO data in 2013, it shows that around 360 million people worldwide have hearing problems. From the 2013 Riskesdas data, around 2.6\% experienced hearing loss and hearing loss at over five years Ri (2013).

The prevalence of CSOM in Indonesia is generally around 3.9\%. In Indonesia, according to a survey conducted in 7 provinces in 1996, the most morbidity in the middle ear is CSOM, especially for benign CSOM, around 3\% Jensen et al. (2013).

Based on the background description above, the authors can formulate the following problem "What is the profile of Benign Type CSOM sufferers at RSU Christian University of Indonesia for the period January 2017 - December 2018?" This study aimed to determine the profile of benign type CSOM patients at the Indonesian Christian University Hospital for the period January 2017 - December 2018.

\section{LITERATURE REVIEW}

The ear is an organ that functions like hearing and balance are divided into three parts: the outer ear, middle ear, and inner ear. The outer ear and middle ear transmit sound to the inner ear. The inner ear contains organs for hearing and balance Water (2012).

The outer part of the ear consists of the auricula (earlobe), meatus acoustics Externa (outer ear hole), canalis auricularius externus (outer ear canal), with a limit to the outside of the tympanic membrane. Auricula is covered with skin and is formed by fibroblasts cartilage. The ear lobe without cartilage is called the lobules auricula Landegger et al. (2017). Meatus acusticus externa is a tube in the shape of the letter $\mathrm{S}$. The wall consists of cartilage and bone. The cartilage includes $1 / 3$ the lateral, and the bone covers $2 / 3$ the medial. All MAE is covered by skin, and some are covered with hair, and sudoriferous calendula will produce wax Drake et al. (2014).The 


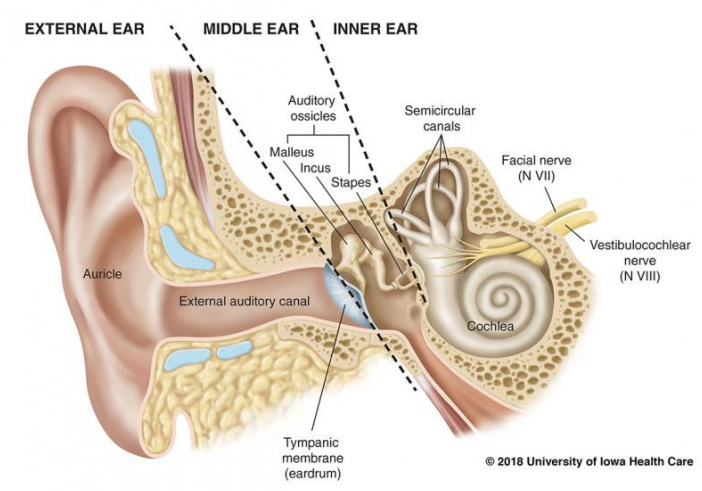

Figure 1 Ear Anatomy

middle ear includes the tympanic membrane, tympanic cavity, eustachian tube, to the mastoid. The tympanic membrane is shaped like a cone with a peak known as an umbo divided into two parts, namely pars tensa and pars flasides. The pars tensa has 3 layers (stratum cutaneum, stratum fibrosum, and stratum mucosum). Whereas the flasid pars only have two layers (stratum cutaneum and stratum mucosum) Kotikoski (2004).

Mucous membranes cover the tympanic cavity (middle ear space), and there are two muscles, namely M.tensor tympanic and M.stapedius. One of these two muscles' functions is to dampen sounds that are too loud so that damage to the cochlea can be prevented Landegger et al. (2017).The front of the tympanic cavity through the auditival tube and antrum mastoid is directly connected to the nasopharynx Dornhoffer (2014). In the tympanic cavity, there are three hearing bones, namely the malleus, incus, and stapes. The malleus is the largest of the hearing bones, and the incus consists of the corpus, including the crus longum and the crus breve, while the stapes are the most medial of the hearing bones Drake et al. (2014).

The mastoid is a bony cavity whose contents are air. In mastoiditis cases, it occurs because the pus that comes out of the patient with otitis media infects the bone. The inner ear consists of labyrinths osseous and labyrinths membranaceus. Labyrinthus osseus: a) Vestibule; b) Three semicircular canals; and c) cochlea. This labyrinth is lined by the periosteum and contains the perilymph Kotikoski (2004). Labyrinthus membranaceus: a) The semicircular ducts are inside the semicircular canal; b) Ductus cochlear in the cochlea; and c) the uriculus and sacculus are in the vestibule. This labyrinth contains endolymph Dornhoffer (2014).

When hearing the sound, sound waves will enter through the MAE and head to the tympanic membrane. The sound waves that travel will vibrate the tympanic membrane so that the sound that enters will become mechanical energy Cheng et al. (2013). Vibration of the tympanic membrane will pass through the hearing bones from the malleus to the end of the stapes. The vibrations that occur move the fluid 
in the cochlea, thus moving neurons on the bacillary membrane. The movement of neurons will convert the mechanical energy into nerve impulses through the organ of Corti. Through the auditory nerve, transmitted impulse in the brain are processed, so that loud voices and sounds can be recognized Cheng et al. (2013).

An infection due to tympanic membrane perforation characterized by continuous or intermittent discharge.Inflammation of the mucosa of mastoid cells is common and irreversible Yamamoto et al. (2017). The dominant symptoms of CSOM are discharged from the ear and hearing loss. Most patients with CSOM have temporary or permanent hearing loss, with average hearing levels usually between 10 and 40 decibels.

Determine the type of CSOM that can be seen from the perforation of the tympanic membrane. The central perforation is located in the pars tensa, the marginal perforation part of the perforated edge is directly related to the annulus or tympanic groove, the perforation adjusts the location of the perforation in the flasid pars. Based on the secretion activity: a) active CSOM, namely secretions from the tympanic cavity that are actively emitted; b) Calm CSOs, namely wet or dry timpani kavum Dolan and Abbas (1985).

Based on the perforation: a) Benign type CSOM (safe type) - This type of CSOM is common without cholesteatoma. The perforation is centrally located. Only the mucosa and complications are rare; and b) malignant type CSOM (hazard type) CSOM is not only on the mucosa but can also reach the bone. Perforation is marginal, accompanied by cholesteatoma, and complications are common Rout et al. (2012a).

CSOM occurs due to infection with bacteria. The bacteria that cause CSOM are different from the causes of AOM. In CSOM, it is caused by aerobic and anaerobic bacteria. Aerobic bacteria such as Pseudomonas aeruginosa, Proteus mirabilis, S. aureus, Streptococcus pyogenes, Escherichia coli, or Klebsiella sp. Anaerobic bacteria such as Bacteroides, Peptostreptococcus, or Propionibacterium sp. In AOM, it is caused by various kinds of bacteria such as Streptococcus pneumonia, Haemophilus influenzae, Moraxella catarrhalis, and others.

The risk factors for CSOM are allergy, history of ARI14, and history of OMA1. CSOM occurs starting from inflammation and irritation of the middle ear mucosa caused by multiple factors, including caused by bacteria or viruses, allergies, impaired tubal function, and socioeconomic environment. As a form of inflammatory reaction, there will be mucosal oedema. If it continues to walk it will cause ulcers and damage the epithelium. The immune system will try to deal with the infection and inflammation resulting in granulation tissue, polyps in the middle ear space. If not managed properly, the tissue around the bone is damaged, and various complications arise Maroldi et al. (2001).

Clinical Manifestations of Chronic Suppurative Otitis Media Benign Type: a) Discharge (otorrhea) depending on the type. In the benign type, the secretions are usually mucoid, less foul-smelling, and intermittent; b) There is hearing loss such as conductive hearing loss; c) There was a perforation of the tympanic membrane, namely 
the central perforation; and d) Inflammation is only found in the mucosal area Juyal et al. (2013).

The diagnosis of CSOM can be made by history, physical examination, and supporting examinations if needed. The diagnosis criteria for CSOM are persistent inflammation of the middle ear or mastoid cavity, recurrent or persistent otorrhea through the tympanic membrane's perforation. In the history, there is a history of discharge from the middle ear for $>2$ months Kong and Coates (2009). Patients usually have a history of recurring AOM. No pain in the ear. The physical examination can be performed as an inspection of the auricula and postauricular. Palpation is done to assess whether there is tenderness in the mastoid process Mathieson et al. (2009); Netter (2018). An otoscope examination can also be done to see the condition of the tympanic membrane, such as the location of the perforation, oedema, inflammation, and fluid.

In supporting an examination of CSOM Benign Type: a) Automicroscopic/otoendoscopic examination; b) Examination by tuner and audiometric tests for hearing function; c) Examination to determine the function of the eustachian tube Rout et al. (2012b); and d) Mastoid plain radiograph examination. Meanwhile, Benign Type CSOM is carried out through conservative therapy and Operative CSOM Benign Type.

\section{RESEARCH METHOD}

This study is a descriptive and retrospective cross-sectional study, where the data collected is based on the patient's medical record. This research was conducted in October - November 2019 at the medical records section of the UKI Hospital. The population in this study were chronic suppurative otitis media patients at the ENT Poli UKI Hospital. The research sample taken was the benign type of CSOM in the ENT Poli UKI Hospital. Subjects in this study, namely inclusion criteria and exclusion criteria. This study's research instrument was the medical records of benign type CSOM patients at UKI Hospital. All data collected is then processed using Electronic Data Processing (EDP) via a computer in tables. The data that has been collected will be analyzed using univariate analysis. The univariate analysis describes the frequency distribution of the variables to be studied. Data will be compiled computerized using the Statistical Program For Social Science (SPSS) for Windows program.

\section{RESULT AND DISCUSSION}

This research was conducted in the medical records section of the UKI Hospital by taking secondary data from all Benign type CSOM patients at the UKI Hospital in January 2017-December 2018. From the research conducted using the total sampling method, a total sample of 110 patients was obtained. Sixty patients met the inclusion criteria, and 50 patients did not meet the study criteria. Data processing used univariate analysis to describe patients' profile with Benign CSOM based on variables 
of gender, age, ear involved, clinical symptoms, risk factors, and tympanic membrane perforation. The research results can be seen in the table below:

\begin{tabular}{ccc}
\hline $\begin{array}{l}\text { Table } 1 \\
\text { Patients by Gender }\end{array}$ & $\begin{array}{c}\text { Distribution } \\
\text { of }\end{array}$ & Benign CSOM \\
\hline Gender & Frequency (n) & Percentage (\%) \\
Male & 27 & 45.0 \\
\hline Female & 33 & 55.0 \\
Total & 60 & 100.0 \\
\hline
\end{tabular}

Based on the table above, it was found that Benign type CSOM patients mostly suffered by female sex with a total of 33 patients (55\%) of 60 patients and male gender as many as 27 patients (45\%).

\begin{tabular}{|ccc}
\hline $\begin{array}{l}\text { Table } 2 \\
\text { Patients by Age }\end{array}$ & \multicolumn{1}{l}{ Distribution of Benign Type CSOM } \\
\hline Age & Frequency (n) & Percentage (\%) \\
\hline 0-4 year & 1 & 1.7 \\
5-9 year & 3 & 5.0 \\
\hline 10-14 year & 1 & 1.7 \\
\hline 20-24 year & 4 & 6.7 \\
\hline 25-29 year & 5 & 8.3 \\
\hline 30-34 year & 6 & 10.0 \\
\hline $35-39$ year & 7 & 11.7 \\
\hline 40-44 year & 4 & 6.7 \\
\hline $45-49$ year & 6 & 10.0 \\
\hline $50-54$ year & 7 & 11.7 \\
\hline $55-59$ year & 10 & 16.7 \\
\hline $60-64$ year & 4 & 6.7 \\
\hline $75-79$ year & 2 & 3.3 \\
\hline Total & 60 & 100.0 \\
\hline
\end{tabular}

Based on the table above, ten people (16.7\%) have the most Benign Type CSOM patients with an age range of 55-59 years, and at least one person (1.7\%).

\begin{tabular}{|c|c|c|}
\hline Infected ear & Frequency (n) & Percentage (\%) \\
\hline Right & 35 & 58.3 \\
\hline Left & 16 & 26.7 \\
\hline Bilateral & 9 & 15.0 \\
\hline Total & 60 & 100.0 \\
\hline
\end{tabular}

From the table above, it was found that the ear that was infected in CSOM Benign Type was the right ear, mostly 35 people (58.3\%), followed by 16 people $(26.7 \%)$ left 
ear, and the least was bilateral (both ears) as many as nine people (15\%).

\begin{tabular}{ccc}
\hline Table 4 Distribution of Benign Type CSOM Patients based on Clinical Symptoms \\
\hline Clinical Symptoms & Frequency(n) & Percentage (\%) \\
\hline Store & 46 & 76.7 \\
hearing loss & 10 & 16.7 \\
a feeling of fullness in the ear & 3 & 5.0 \\
\hline Tinnitus & 1 & 1.7 \\
\hline Total & 60 & 100.0 \\
\hline
\end{tabular}

From the table above, it was found that the most clinical symptoms in CSOM Benign Type were otorrhea (discharge from the ear) as many as 46 people $(76.7 \%)$ followed by a decreased hearing in 10 people (16.7\%), full feeling in the ears of 3 people (5\%), and the least amount of tinnitus was one person $(1.7 \%)$.

Table 5 Distribution of Benign Type CSOM Patients based on Risk Factors

\begin{tabular}{|ccc|}
\hline Risk Factors & Frequency(n) & Percentage (\%) \\
\hline previous otitis media & 53 & 88.3 \\
Eustachian tube obstruction & 3 & 5.0 \\
ARI & 2 & 3.3 \\
Allergy & 2 & 3.3 \\
\hline Total & 60 & 100.0 \\
\hline
\end{tabular}

From the table above, it was found that the most risk factors for the occurrence of benign type CSOM were the previous history of otitis media as many as 53 people (88.3\%), followed by blockage of the eustachian tube three people (5\%), two people with ARI (3.3\%) and allergies two people (3.3\%).

Table 6 Distribution of Benign CSOM Patients based on Tympanic Membrane Perforation

\begin{tabular}{ccc}
\hline $\begin{array}{c}\text { Tympanic membrane } \\
\text { perforatio }\end{array}$ & Frequency(n) & Percentage (\%) \\
Central & 57 & 95.0 \\
Subtotal & 3 & 5.0 \\
Total & 60 & 100.0 \\
\hline
\end{tabular}

Based on the table above, it was found that the most tympanic membrane perforations were central perforation as many as 57 people (95\%), subtotal tympanic membrane perforations as many as three people (5\%). This research is a descriptive study and was conducted using a cross-sectional retrospective method. Based on Benign Type CSOM patients' medical record data at UKI Hospital from January 2017 to December 2018 who met the research criteria, there were 60 patients.

The results showed that there were 60 patients with CSOM Benign Type in RSU UKI, the highest proportion based on gender was 33 people (55\%), while 27 men 
(45\%) were male. This research is in line the result of the reseach that shows 106 female patients (52\%), while 99 male patients (48\%) of the total number of patients 205 people Ludman and Bradley (2012).

However, the results of this study are not in line with the research that showed the total number of respondents was 107 people, it was found that the male gender was more, namely 72 people $(67.3 \%)$ and 35 female sex (32.7\%). This is due to the habit of men doing work outside the environment, so they are prone to infection Netter (2018).

This study showed that patients with the benign type of CSOM based on age obtained the most significant proportion of age were aged 55-59 years, amounting to 10 people $(16.7 \%)$. Then it is followed by ages $35-39$ years and ages $50-54$ years as many as seven people (11.7\%. ); aged 30-34 years and ages $45-49$ years as many as six people (10\%); 5 people aged $25-29$ years (8.3\%); 4 people aged $20-24$ years, 40-44 years old, and 65-69 years old (6.7\%); aged 5- 9 years as many as three people (5\%); 2 people aged 75-79 years (3.3\%); and the lowest proportion of age is $0-4$ years old and 10-14 years old as many as one person (1.7\%). This research is not in line with the research conducted by Debora M Pangemanan et al. at Prof. Dr R. D. Kandou Manado in 2014-2016, where out of 78 people, the most people suffering from CSOM were 18-40 years old, amounting to 30 people (38\%) followed by the age of 41-65 years as many as 18 people. This can be caused by a lack of attention to hygiene, sanitation and ear health "Addressing the rising prevalence of hearing loss" (2018).

Based on the results of research on patients with Benign Type CSOM, it was found that the most infected ear was the right ear as many as 35 people (58.3\%) followed by the left ear 16 people (26.7\%), and the least was bilateral (both ears) as many as nine people. (15\%). This research is in line with the research that said the number of respondents was 23 people, the highest proportion was right ear nine people (39.1\%) and the lowest was left ear (26.1\%) Lisa and Wibawa (2013).

Based on the results of the study of patients with Benign Type CSOM, it was found that the most complained of clinical symptoms was otorrhea (discharge from the ear) as many as 46 people (76.7\%) and the least was tinnitus one person $(1.7 \%)$. This research is in line with the research that showed where the clinical symptoms of otorrhea were found as many as 167 people (81\%) Al-Maidin (2016). This research is also in line with the research conducted by Nurul Annisari Al-Maidin at RSUP DR. Wahidin Sudirohusodo Makassar in 2016-2017, where the clinical symptoms of otorrhea were obtained as many as 56 people (54.2\%) Srivastava et al. (2010).

Based on the results of the study, it was found that the most risk factor was a history of previous otitis media, as many as 53 people $(88.3 \%)$. The risk factors for $\mathrm{ARI}$ and allergies were the same, as many as two people $(3.3 \%)$. This research is in line with research that showed where the most risk factors for the history of AOM, followed by allergies Pangemanan et al. (2016a). 
Based on the results of the study, it was found that the highest proportion of tympanic membrane perforations was central perforation as many as 57 people (95\%) and the lowest was subtotal as many as three people (5\%). This study is in line with the research which showed 44 people $(81.5 \%)$ of central perforations Pangemanan et al. (2016b). This research is also in line with the research that found 59 people with CSOM with central perforation (90.8\%).

\section{CONCLUSION}

CSOM is a chronic inflammation of the middle ear characterized by intermittent or continuous discharge, perforation of the tympanic membrane, and hearing loss. CSOM Benign type is a type of CSOM in which there is no cholesteatoma, inflammation only of the mucosa, and does not cause dangerous complications. Based on research conducted at the UKI Hospital in 2017-2018, it can be concluded: a) the highest proportion of CSOM patients with Benign Type based on gender was female as many as 33 people (55\%); b) the highest proportion of people with CSOM Benign Type based on age is the age group 55-59 years as many as ten people (16.7\%); c) the highest proportion of people with CSOM Benign Type based on the infected ear was the right ear as many as 35 people (58.3\%); d) The highest proportion of CSOM patients with Benign Type based on Clinical Symptoms was otorrhea (discharge from the ear) which mainly was complained of by 46 people (76.7\%); e) the highest proportion of CSOM patients with Benign Type based on risk factors was a previous history of otitis media, amounting to 53 people (88.3\%); and f) the highest proportion of patients with benign type CSOM based on tympanic membrane perforation was central perforation as many as 57 people (95\%).

\section{REFERENCES}

Addressing the rising prevalence of hearing loss. (2018). World Health Organization.

Al-Maidin, N. A. (2016). Characteristics of chronic suppurative otitis media patients at the central public hospital dr. Wahidin Sudirohusodo for the period. Makassar: Universitas Hasanuddin, Fakultas Kedokteran.

Cheng, J. T., Hamade, M., Merchant, S. N., Rosowski, J. J., Harrington, E., \& Furlong, C. (2013). Wave motion on the surface of the human tympanic membrane: Holographic measurement and modeling analysis. The Journal of the Acoustical Society of America, 133(2), 918-937. Retrieved from https://dx.doi.org/10.1121/1.4773263 10.1121/ 1.4773263

Chonmaitree, T., Jennings, K., Golovko, G., Khanipov, K., Pimenova, M., Patel, J. A., McCormick, D. P., Loeffelholz, M. J., \& Fofanov, Y. (2017). Nasopharyngeal microbiota in infants and changes during viral upper respiratory tract infection and acute otitis media. PLOS ONE, 12(7), e0180630-e0180630. Retrieved from https://dx.doi.org/ 10.1371/journal.pone.0180630 10.1371/journal.pone.0180630

Chronic suppurative otitis media: burden of illness and management options. (2004). World Health Organization. 
Dolan, T. G., \& Abbas, P. J. (1985). Changes in the 2f1-f2 acoustic emission and whole-nerve response following sound exposure: Long-term effects. The Journal of the Acoustical Society of America, 77(4), 1475-1483. Retrieved from https://dx.doi.org/10.1121/1 $.39204210 .1121 / 1.392042$

Dornhoffer, J. L. (2014). A practical guide to the eustachian tube. Springer. A practical guide to the eustachian tube.

Drake, R. L., Vogl, A. W., \& Mitchell, A. W. (2014). Basics of Gray's Anatomy. Basics of Gray's Anatomy.

Jensen, R. G., Koch, A., \& Homøe, P. (2013). The risk of hearing loss in a population with a high prevalence of chronic suppurative otitis media. International Journal of Pediatric Otorhinolaryngology, 77(9), 1530-1535. Retrieved from https://dx.doi.org/10.1016/ j.ijporl.2013.06.025 10.1016/j.ijporl.2013.06.025

Juyal, D., Negi, V., Pal, S., Adekhandi, S., Sharma, M., Sharma, N., \& Prakash, R. (2013). Microbiology of chronic suppurative otitis media in a tertiary care setup of Uttarakhand state, India. North American Journal of Medical Sciences, 5(4), 282-282. Retrieved from https://dx.doi.org/10.4103/1947-2714.110436 10.4103/1947-2714.110436

Kong, K., \& Coates, H. L. C. (2009). Natural history, definitions, risk factors and burden of otitis media. Medical Journal of Australia, 191(S9), 39-43. Retrieved from https://dx.doi.org/ 10.5694/j.1326-5377.2009.tb02925.x 10.5694/j.1326-5377.2009.tb02925.x

Kotikoski, M. (2004). Acute Myringitis in Children less than Two Years of Age. Acute Myringitis in Children less than Two Years of Age.

Landegger, L. D., Pan, B., Askew, C., Wassmer, S. J., Gluck, S. D., Galvin, A., Taylor, R., Forge, A., Stankovic, K. M., Holt, J. R., \& Vandenberghe, L. H. (2017). A synthetic AAV vector enables safe and efficient gene transfer to the mammalian inner ear. Nature Biotechnology, 35(3), 280-284. Retrieved from https://dx.doi.org/10.1038/nbt.3781 10.1038/ nbt.3781

Lisa, A. N., \& Wibawa, F. S. (2013). Characteristics Of Chronic Supurative Media Otitical Patients (Omsk. Jurnal Ilmu Kedokteran dan Kesehatan(4), 1-1.

Ludman, H. S., \& Bradley. (2012). ABC of ear, nose and throat. In P. J. (Ed.), ABC of ear, nose and throat (Vol. 254). John Wiley \& Sons.

Maroldi, R., Farina, D., Palvarini, L., Marconi, A., Gadola, E., Menni, K., \& Battaglia, G. (2001). Computed tomography and magnetic resonance imaging of pathologic conditions of the middle ear. European Journal of Radiology, 40(2), 78-93. Retrieved from https:// dx.doi.org/10.1016/s0720-048x(01)00376-x 10.1016/s0720-048x(01)00376-x

Mathieson, L., Hirani, S. P., Epstein, R., Baken, R. J., Wood, G., \& Rubin, J. S. (2009). Laryngeal Manual Therapy: A Preliminary Study to Examine its Treatment Effects in the Management of Muscle Tension Dysphonia. Journal of Voice, 23(3), 353-366. Retrieved from https://dx.doi.org/10.1016/j.jvoice.2007.10.002 10.1016/j.jvoice.2007.10.002

Netter, F. H. (2018). ABC of ear, nose and throat. Atlas of Human Anatomy: Latin Terminology E-Book: English and Latin Edition.

Pangemanan, D. M., Palandeng, O. I., \& Pelealu, O. C. (2016a). Otitis Media Supuratif Kronik di Poliklinik THT-KL RSUP Prof. Dr. RD Kandou Manado Periode Januari 2014-Desember. CliniC, 6(1).

Pangemanan, D. M., Palandeng, O. I., \& Pelealu, O. C. (2016b). Otitis Media Supuratif Kronik di Poliklinik THT-KL RSUP Prof. Dr. RD Kandou Manado Periode Januari 2014-Desember. CliniC, 6(1).

Ri, B. K. (2013). Basic Health Research. RISKESDAS. Jakarta: Balitbang Kemenkes RI, 110-119. Rout, M., Mohanty, D., Vijaylaxmi, Y., Kamalesh, B., \& Chakradhar, M. (2012a). Prevalence 
of cholesteatoma in chronic suppurative otitis media with central perforation. Indian Journal of Otology, 18(1), 7-7. Retrieved from https://dx.doi.org/10.4103/0971-7749 98280 10.4103/0971-7749.98280

Rout, M., Mohanty, D., Vijaylaxmi, Y., Kamalesh, B., \& Chakradhar, M. (2012b). Prevalence of cholesteatoma in chronic suppurative otitis media with central perforation. Indian Journal of Otology, 18(1), 7-7. Retrieved from https://dx.doi.org/10.4103/0971-7749 98280 10.4103/0971-7749.98280

Rout, M., Susritha, K., Das, P., Jyothi, B. S., Mohanty, D., \& Rao, V. (2014). Ossicular chain defects in safe type of chronic suppurative otitis media. Indian Journal of Otology, 20(3), 102-102. Retrieved from https://dx.doi.org/10.4103/0971-7749.136838 10.4103/ 0971-7749.136838

Singer, A. E. A., Awad, O. G. A.-N., El-Kader, R. M. A., \& Mohamed, A. R. (2018). Risk factors of sensorineural hearing loss in patients with unilateral safe chronic suppurative otitis media. American Journal of Otolaryngology, 39(2), 88-93. Retrieved from https://dx .doi.org/10.1016/j.amjoto.2018.01.002 10.1016/j.amjoto.2018.01.002

Srivastava, A., Singh, R. K., Varshney, S., Gupta, P., Bist, S. S., Bhagat, S., \& Gupta, N. (2010). Microbiological evaluation of an active tubotympanic type of chronic suppurative otitis media. Nepalese Journal of ENT Head and Neck Surgery, 1(2), 14-16.

Water, T. R. V. D. (2012). Historical Aspects of Inner Ear Anatomy and Biology that Underlie the Design of Hearing and Balance Prosthetic Devices. The Anatomical Record: Advances in Integrative Anatomy and Evolutionary Biology, 295(11), 1741-1759. Retrieved from https://dx.doi.org/10.1002/ar.22598 10.1002/ar.22598

Yamamoto, K., Yamato, M., Morino, T., Sugiyama, H., Takagi, R., Yaguchi, Y., Okano, T., \& Kojima, H. (2017). Middle ear mucosal regeneration by tissue-engineered cell sheet transplantation. npj Regenerative Medicine, 2(1), 1-11. Retrieved from https://dx.doi .org/10.1038/s41536-017-0010-7 10.1038/s41536-017-0010-7 